\title{
Effect of Diet on Milk Yield of the Ewe and Growth of her Lamb
}

\author{
By W. THOMSON and A. M. THOMSON \\ Rowett Research Institute, Bucksburn, Aberdeenshire
}

(Received 5 December I952)

We have already reported on the lambing of Sutherlandshire Cheviot ewes maintained during the latter half of pregnancy on either a high or a low plane of nutrition (Thomson \& Thomson, I948-9). Under the dietary conditions imposed in that experiment the low-plane ewes produced small, weakly lambs, many of which died at birth or soon after, and the high-plane ewes produced vigorous lambs amongst which there were few deaths. The present paper deals with the lactation performance of the ewes and with the food consumption and the growth of the lambs; it covers the period March to August I947. The literature has been reviewed by Wallace (1948), who also studied milk yields from ewes maintained on different planes of nutrition. Barnicoat, Logan \& Grant (I949) also have made milk-yield trials on 200 Romney ewes.

\section{EXPERIMENTAL}

General. Soon after parturition the ewes and lambs were arranged in four groups: (I) high-plane ewes suckling their own lambs (H.H.), (2) high-plane ewes suckling lambs born of low-plane ewes (L.H.), (3) low-plane ewes suckling their own lambs (L.L.) and (4) low-plane ewes suckling lambs born of high-plane ewes (H.L.).

All twins were suckled as singles, and all lambs were weaned at $\mathbf{1}_{7}$ weeks of age. The numbers available for the various groups are shown in Table $\mathbf{I}$.

Table I. Numbers of animals in the four groups

\section{Ewes}

Lambs at beginning of suckling period

Lambs weaned

Pairs used in milk-yield trials

Losses during lactation:

L.L. One lamb died at 53 days of age. This lamb was the smallest of the group and weighed only $7.7 \mathrm{~kg}$. There was no apparent cause of death but the carcass was emaciated. Its mother had very little milk.

H.L. One ewe died 6 days after lambing and its lamb was removed from experiment. One ewe had mastitis on the 24 th day and its lamb was removed from experiment. Three lambs died on the 3 rd, $7^{\text {th }}$ and $5^{8 \text { th }}$ days, respectively, presumably because of milk shortage.

$$
\text { * See above. }
$$

In making up these groups all high-plane singles and nine twin-born lambs were used; the remaining twins were discarded. All the surviving low-plane singles and twins were used, including three singles and three twin-born that had been classed 
as 'presumptive neo-natal deaths' in the original paper (Thomson \& Thomson, I948-9). These weakly lambs, which had collapsed from starvation and cold, were revived by heat treatment and bottle-feeding on ewe's milk for a few days.

No difficulty was experienced in transferring a low-plane lamb to a high-plane ewe. The ewe had her own lamb removed about 5 p.m. The low-plane lamb to be transferred to her was given a good feed about midnight (sometimes from a bottle, since often its own mother had little to offer) and was then removed from its mother. Both lambs were housed beyond their mothers' hearing. Between 7 and $8 \mathrm{a} . \mathrm{m}$. on the following day the foster lamb was put in the passageway outside the foster-mother's pen and the animals were left to bleat to one another for about $15 \mathrm{~min}$, after which they were successfully introduced. Transferring a high-plane lamb to a low-plane ewe was less easy, and for some weeks after the transfer the ewes generally had to be held while the lambs sucked. As mentioned in our earlier paper, maternal instinct appeared greatest when there was a full udder (Thomson \& Thomson, r $94^{8-9}$ ).

Udder width. At lambing the udder width of each ewe was measured at its widest point across the line of the teats and also from point to point of the teats; only the former measurement is used in this paper.

Diet of ewes. From lambing the diet of all ewes consisted of concentrates $\mathrm{I} \frac{1}{2}$, swedes 3 and hay I part, with $5 \mathrm{ml}$. cod-liver oil per ewe daily. When swedes were out of season grass was used instead: it contained a high proportion of perennial ryegrass and small proportions of cocksfoot and wild white clover; $0.5 \mathrm{lb}$. of it replaced I lb. swedes. In estimating the gross digestible energy and protein equivalent this grass was considered as 'Spring grass running off during summer' (Wood \& Woodman, 1939). All ewes were fed individually three times daily and had access to water, salt and mineral licks at all times. The concentrate mixture was the same as that given during gestation, and in Figs. I $A$ and $B$ the amount of food consumed is shown in terms of gross digestible energy (G.D.E.) and protein equivalent (P.E.). Whether or not the ewes were on milk-yield trials (see below), the amount fed to each ewe within a group was much the same.

Acting on the principle that the lactating animal has a greater nutritional requirement than the pregnant one, the food allowance for all groups was increased during lactation. It was the intention originally to give the same amount of food to lowplane ewes suckling high-plane lambs as to those suckling low-plane lambs, but it soon became evident that the milk supply would have to be increased if the lambs transferred from high- to low-plane ewes were to survive. In an attempt to increase the milk flow of the low-plane foster-ewes their food allowance was therefore raised, as rapidly as they would take it, to the level of that of the high-plane ewes.

Diet of lambs. As soon as they would eat, the lambs were allowed hay, grass and the same concentrate mixture as the ewes. Within their respective groups they had at all times access to these foods and to water, salt and mineral licks, but not to the ewes' rations. Cod-liver oil was added to the concentrates daily at the rate of $2.5 \mathrm{ml} / \mathrm{lamb}$. They could not be fed individually, but the daily food consumption for each group or subgroup was ascertained. All lambs were weighed daily.

Milk-yield trials. Certain ewes and lambs from each group were used for milk-yield 
trials by the following method. The basis of selection for those suckling their own lambs was chance, in so far as the choice depended only on convenience of the date of birth; for those transferred from one or other of the groups the decisions were made when ewes in both high- and low-plane groups lambed within a day or so of one
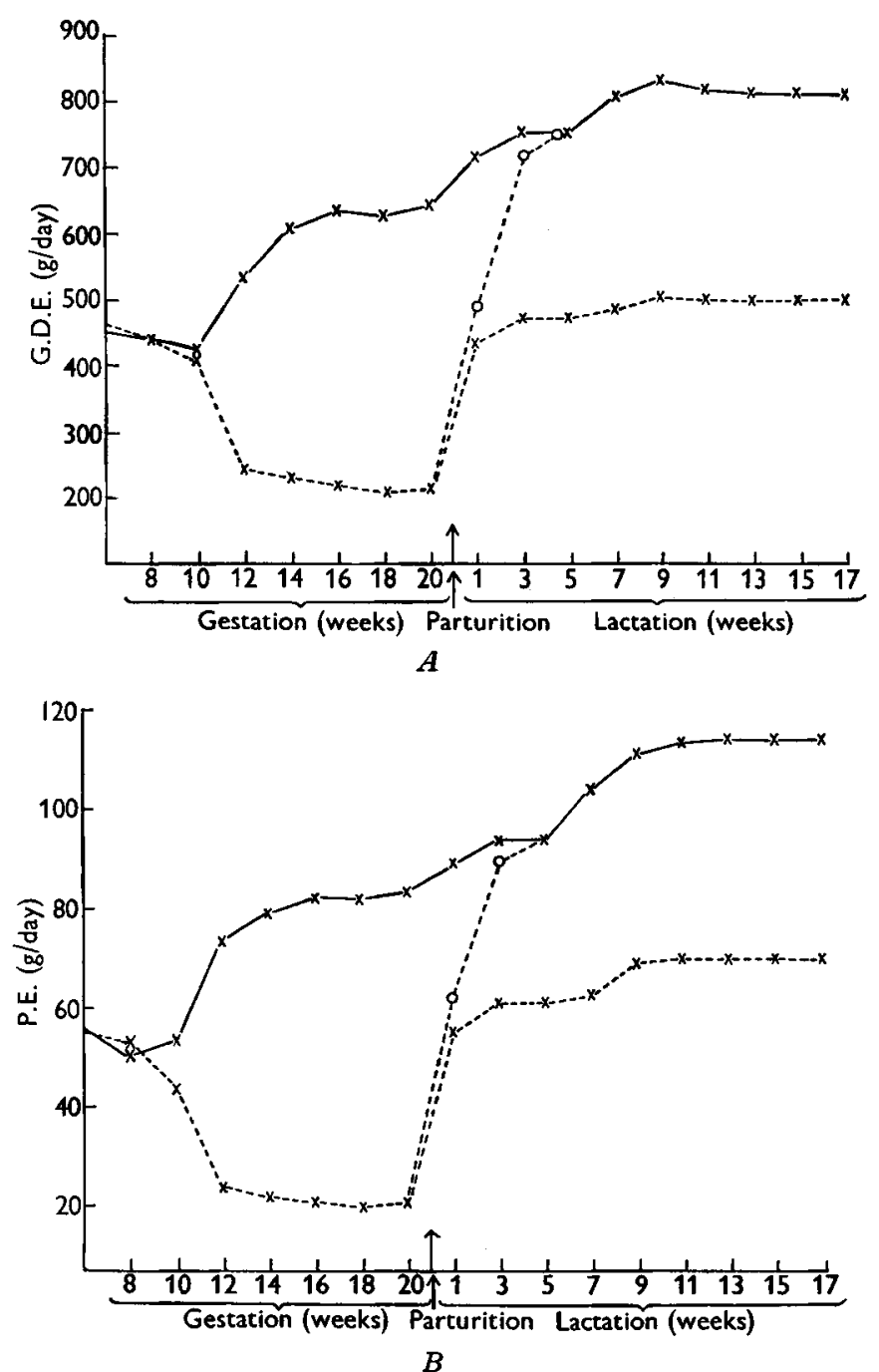

Fig. I. Average daily food consumption of ewes in terms of $(A)$ gross digestible energy (G.D.E.) and

$(B)$ protein equivalent (P.E.). $\times-\times$, ewes with H.H. and L.H. lambs; $0----0$, ewes with H.L. lambs; $\times \cdots---x$, ewes with L.L. lambs.

another, so that suitable transfers or exchanges could be made. This was done as soon as practicable after the foster-mothers lambed. The lambs were kept apart from the ewes in pens of up to four lambs each; on either side of these were their mothers or foster-mothers in individual tubular pens, so that they could see each other. The lambs were put to suck four times daily, at 6 and I a.m. and at 4 and Io p.m. They were weighed before and after sucking, and the weight difference was assumed to be the 
weight of milk consumed. We had used this method successfully in the previous year, and it has also been used by Wallace (1948) and by others quoted by him. Up to a weight of about ro $\mathrm{kg}$ the lambs were weighed to the nearest $5 \mathrm{~g}$ on an Avery visiblescale damped balance. Above this weight they were weighed on an Avery platform type machine, which weighed to the nearest $\frac{1}{2} \mathrm{oz}$. However, when the lambs reached weights beyond $25 \mathrm{~kg}$ this balance became progressively more erratic, until it was impossible to weigh on it a lively lamb to within $2 \mathrm{oz}$. in successive weighings. Consequently the trials stopped for the heavier lambs at 9I days. They were still kept apart from their mothers, however, and put to suck at the stated times, and an attempt was made to get the milk consumption of each during the last $24 \mathrm{~h}$ before weaning at I 9 days.

\section{RESULTS}

Weight curves of ewes. Mean weight curves of the ewes from the 6th week of gestation to the day of weaning are shown in Fig. 2. The average weight changes of those ewes on milk-yield trials did not vary greatly from the overall averages shown. In compiling these curves the wool clip had to be considered. For the animals' comfort they had to be shorn towards the end of June when at stages in lactation from the 6 th to the IIth week. In constructing the curves, therefore, the fleece weights shown in Table 2 were added to the body-weights at the time of shearing.

Table 2. Average weights with their standard errors of unwashed fleece of ewes at normal shearing time ( $F u n e$ )

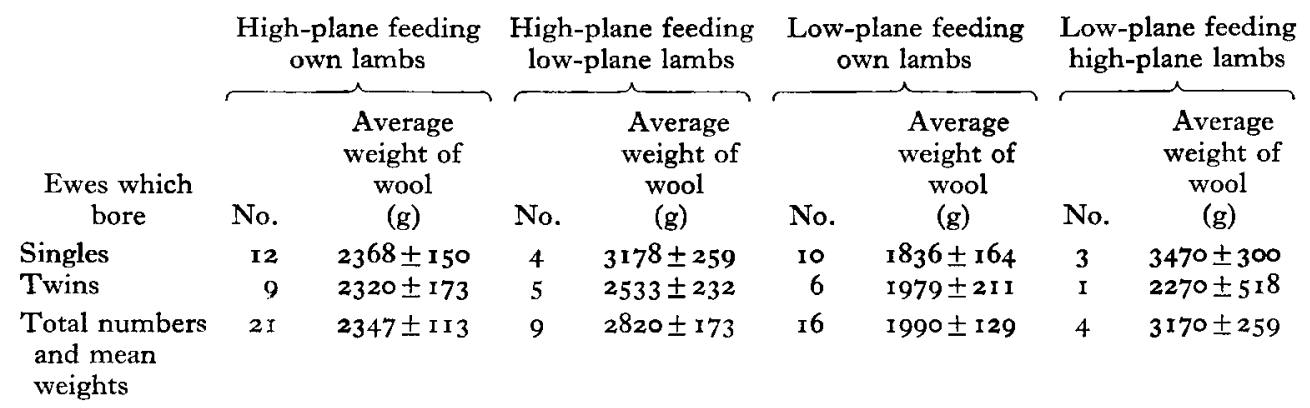

S.E. based on 42 degrees of freedom. There is no significant group difference.

Despite the substantial increase in food supply after lambing, there was some loss of weight in the H.H., L.H. and L.L. groups (Fig. 2). This may have adversely affected the milk supply, although it is common knowledge that dairy cows usually lose weight at the height of lactation in spite of good feeding. However, there is no reason to assume in the present instance that the ewes would not have eaten more food if offered it. Although the H.L. group ewes increased in weight, it is obvious from the lactation curves in Fig. 3 that there was no substantial rise in milk production.

Lactation. Lactation curves in Fig. 3 are based on 5 -day intervals, each point being the daily average of 5 days. There were very wide daily variations, which make the curves difficult to separate when based on I-day intervals. These fluctuations, still evident in the curves as presented, are difficult to explain. They were most decided 
in the two high-plane groups of ewes, and they cannot be related to environment since there was a spread of about 3 weeks in lambing dates, so that on any particular day not all the ewes were at the same stage in lactation. Fluctuations were not so evident in the L.L. group or in the H.L. group until late in the lactation period One important feature was the very rapid rise to the peak in the lactation curves of the

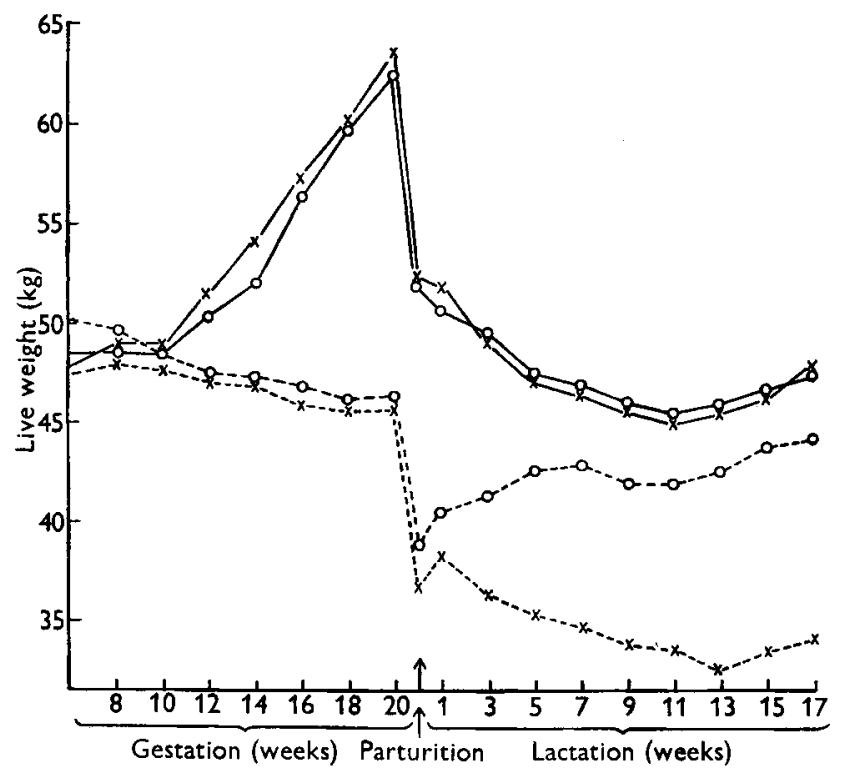

Fig. 2. Weight curves of ewes that suckled lambs. $\times-x$, ewes with H.H. lambs (twenty-one ewes); $0-0$, ewes with L.H. lambs (nine ewes); $0---0$, ewes with H.L. lambs (four ewes); $\times \cdots \times$, ewes with L.L. lambs (sixteen ewes).

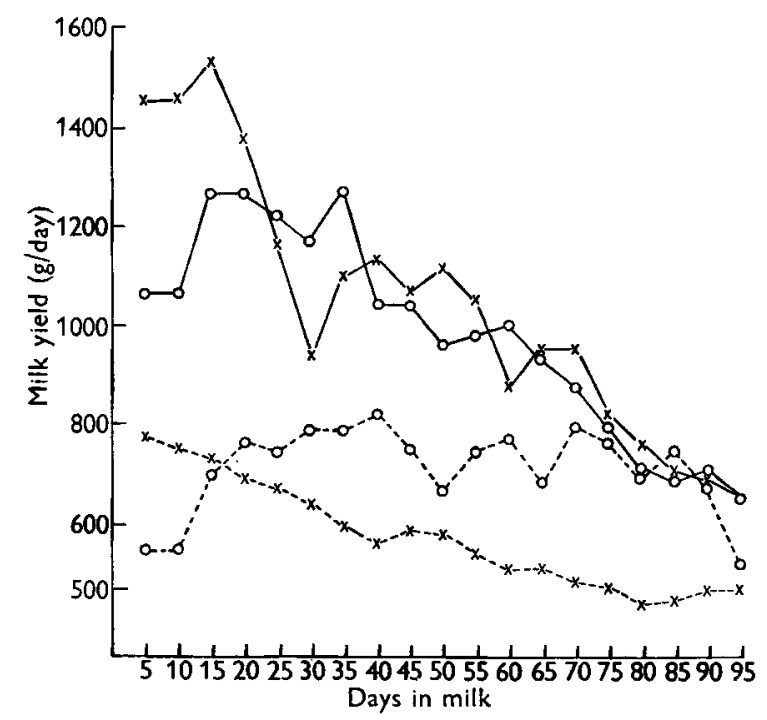

Fig. 3. Average daily milk yield of ewes in 5 -day intervals, $\times-\times$, ewes with H.H. lambs (four ewes); o- o, ewes with L.H. lambs (four ewes); $0-\cdots-0$, ewes with H.L. lambs (three ewes); $\times \cdots \times$, ewes with L.L. lambs (eight ewes). 
H.H. and L.H. groups. Although this peak was reached by the roth day, we are confident that, in the early stages at least, the curve was more a reflexion of the maximum amounts the lambs were able to drink than of the amounts available. It was evident that the lambs in these groups, and in particular the L.H. group, were unable to take all the available milk during the early stages. From these observations it would appear that the peak of production was reached well before the Ioth day, but was retarded because of the capacity of the lamb. This is a point worthy of emphasis, since it implies that udder development and capacity for lactation are governed by the nutrition of the ewe in the later stages of pregnancy. This point is further demonstrated in the curve (Fig. 3) of the H.L. group in which the food of the ewes was increased after lambing as rapidly as the ewes would take it, yet this curve does not finally part from that of the L.L. group until the 2oth day.

Milk yields in Table 3 show that there was little difference between the H.H. and L.H. groups, indicating that the L.H. lambs were capable of taking all the available milk after the first few days. When the lactation period was divided into three equal portions, the H.H., L.H. and L.L. groups each yielded $40-41 \%$ of the total milk

Table 3. Mean values (with their standard errors) of milk yields of ewes and weight increases of lambs

\begin{tabular}{|c|c|c|c|c|c|c|c|c|}
\hline \multirow[b]{2}{*}{ Group } & \multirow{2}{*}{$\begin{array}{l}\text { No. } \\
\text { of } \\
\text { ewes }\end{array}$} & \multicolumn{2}{|c|}{$\begin{array}{c}\text { Total milk yield } \\
5 \text {-9I days }\end{array}$} & \multicolumn{3}{|c|}{ Lamb weight $(\mathrm{kg})$} & \multicolumn{2}{|c|}{ Lamb weight increase $(\mathrm{kg})$} \\
\hline & & $\mathrm{kg}$ & ge & 5 & $91 \mathrm{C}$ & 119 & ays & days \\
\hline 4 & 4 & $89.4 \pm$ & 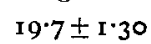 & $6 \cdot 0$ & 25 & 3 & 52 & \\
\hline & 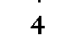 & $86 \cdot 6$ & & & & & & \\
\hline L.L & 8 & $49 \cdot 8 \pm 4.19$ & $10.9 \pm 0.92$ & $3.8 \pm 0.28$ & 18 & $22 \cdot 1$ & 14 & $18.3 \pm 1.50$ \\
\hline$H T$ & 3 & $62 \cdot 9 \pm 6 \cdot 85$ & $13.8 \pm 1.50$ & $4.7 \pm 0.46$ & $19 \cdot 6 \pm 2 \cdot 00$ & $24 \cdot 3 \pm 2 \cdot 69$ & $14.9 \pm 1.76$ & $19 \cdot 6 \pm 2.44$ \\
\hline
\end{tabular}

s.E. based on 15 degrees of freedom. * See text, p. 263 .

yield in the first period, $32-34 \%$ in the second and $25-27 \%$ in the last. The H.L. group, however, yielded about equal proportions in each period. There were only three survivors in the last group, yet the individual percentages at all three stages were almost identical, and this again reflects the delayed effect of increasing the food allowance after lambing. In Table 3 the weight increments of lambs on milk-yield trials are also shown.

Food consumption of lambs on milk-yield trials. In Table 4 are shown the mean figures for consumption of trough feed per lamb up to 199 days of age in terms of G.D.E. and P.E. There was no obvious group difference.

The proportions of these nutrients from the various foodstuffs consumed were about the same for all groups, namely, $90 \%$ from concentrates, $7 \%$ from hay and $3 \%$ from grass. As already mentioned, the lambs were not fed individually but in their respective groups.

Growth of lambs. Although the lambs were weighed daily, it is considered sufficient to show in Table 5 the mean weights at critical points only, namely, at birth, at 40 days (before appreciable amounts of supplementary foods were being consumed) and at weaning. There was no significant difference between the weights of males and females; they have therefore been considered together. 
Twin-born lambs were the lighter at weaning in all groups except the L.L., where, on average, they were of the same weight as single-born lambs. It would appear therefore that the low-plane ewes had just sufficient milk to allow the smaller twinborn lamb to overtake the single-born lamb but insufficient to enable the latter to

Table 4. Total trough feed, in terms of gross digestible energy* and protein equivalent* consumed per lamb weekly by lambs on milk-yield trials

\begin{tabular}{|c|c|c|c|c|c|c|c|c|}
\hline \multirow{2}{*}{$\begin{array}{c}\text { Weeks of } \\
\text { age }\end{array}$} & \multicolumn{4}{|c|}{ G.D.E. (g) } & \multicolumn{4}{|c|}{ P.E. (g) } \\
\hline & H.H.† & L.H.† & L.L.† & H.L.† & H.H.† & L.H.† & L.L.† & H.L. $†$ \\
\hline 3 & $2 \mathrm{I} 4$ & 189 & 274 & 3 II & 32 & 28 & $4 I$ & 47 \\
\hline 4 & 3 I 5 & 334 & 353 & $5 \times 9$ & $4^{8}$ & 50 & 55 & 79 \\
\hline 5 & 605 & 734 & $5^{6} 5$ & $3^{6} 7$ & I I 4 & 117 & 89 & $5^{8}$ \\
\hline 6 & 425 & 396 & 425 & 396 & 64 & $6 I$ & 64 & $6 I$ \\
\hline 7 & 734 & 1,102 & 932 & 734 & 117 & I 76 & 148 & 117 \\
\hline 8 & $\mathrm{I}, 498$ & $\mathrm{I}, 504$ & 1,512 & $\mathrm{I}, \mathrm{I} 59$ & 237 & 238 & 238 & $18 \mathrm{I}$ \\
\hline 9 & 2,034 & 1,865 & $\mathrm{I}, 77 \mathrm{I}$ & $\mathrm{I}, 865$ & 323 & 295 & 275 & 295 \\
\hline IO & 2,016 & 2,523 & 1,658 & $\mathrm{I}, 648$ & 310 & 393 & 253 & $25 \mathrm{I}$ \\
\hline I I & 2,659 & 2,659 & 2,1 I 3 & 2,075 & 420 & 420 & 332 & 316 \\
\hline 12 & 2,933 & 2,933 & $2,3 \circ 3$ & 3,000 & 470 & 470 & 365 & 476 \\
\hline I 3 & $3,04 \circ$ & 3,040 & 2,736 & 3,107 & 486 & 486 & 436 & 492 \\
\hline 14 & 4,140 & 3,628 & 3,472 & 2,955 & 667 & 582 & 557 & 467 \\
\hline I 5 & 4,853 & 4,682 & 4,682 & $5,49 \circ$ & 784 & 756 & 756 & 884 \\
\hline I6 & 5,194 & 5,194 & 4,497 & 6,855 & 841 & $84 I$ & 726 & I, I IO \\
\hline I 7 & 4,170 & 4,170 & 3,785 & 4,806 & 672 & 672 & 6II & 772 \\
\hline Total & 34,830 & 34,953 & 31,078 & 35,287 & $5,5^{8} 5$ & 5,585 & 4,946 & 5,606 \\
\hline & & & $\begin{array}{l}\text { See Wc } \\
\text { See tex }\end{array}$ & $\begin{array}{l}\text { Woo } \\
63 \text {. }\end{array}$ & (r939). & & & \\
\hline
\end{tabular}

Table 5. Mean lamb weights $(\mathrm{kg})$ with their standard errors

Single-born

\begin{tabular}{|c|c|c|c|c|}
\hline Group & No. & At birth & At 40 days & $\begin{array}{l}\text { At } 1 \text { ig days } \\
\text { (weaning) }\end{array}$ \\
\hline H.H.* & 12 & $4 \cdot 7 \pm 0 \cdot 18$ & I $5 \cdot 1 \pm 0.44$ & $31 \cdot 7 \pm r \cdot 29$ \\
\hline L.H.* & 7 & $3 \cdot 2 \pm 0 \cdot 24$ & $12.4 \pm 0.57$ & $28 \cdot 6 \pm \pm \cdot 69$ \\
\hline L.L.** & ro & $3 \cdot 6 \pm 0.20$ & $9 \cdot 3 \pm 0 \cdot 48$ & $2 I \cdot 9 \pm I \cdot 4 I$ \\
\hline H.L.* & 3 & $4 \cdot 9 \pm 0.37$ & I $1.4 \pm 0.87$ & $27 \cdot 8 \pm 2 \cdot 58$ \\
\hline \multicolumn{5}{|c|}{ S.E.'s based on 28 degrees of freedom } \\
\hline \multicolumn{5}{|c|}{ Twin-born (single-reared) } \\
\hline H.H.* & 9 & $3.5 \pm 0.10$ & $13.0 \pm 0.29$ & $27 \cdot 7 \pm 1 \cdot 20$ \\
\hline L.H.* & 2 & $2 \cdot 1 \pm 0.21$ & $9.5 \pm 0.6 I$ & $26 \cdot 8 \pm 2 \cdot 55$ \\
\hline L.L.* & 6 & $2 \cdot 4 \pm 0.12$ & $8 \cdot 3 \pm 0 \cdot 35$ & $22 \cdot 6 \pm I \cdot 47$ \\
\hline H.L.* & $\mathbf{I}$ & $3.4 \pm 0.30$ & $6.8 \pm 0.86$ & $17 \cdot 5 \pm 3 \cdot 60$ \\
\hline
\end{tabular}

reach its potential maximum. Growth curves for single-born lambs only are shown in Fig. 4. Inclusion of the curves for the twin-born lambs tends to complicate the figure without enhancing its value.

It will be noted in Table 6 that the quotient of the weight over the shoulder height has been used as a measure of fatness, or body condition; the greater the quotient, the greater the relative amount of flesh to skeleton. In this and other measurements the L.L. lambs were inferior to the H.H. lambs at birth and at weaning. The H.L. 


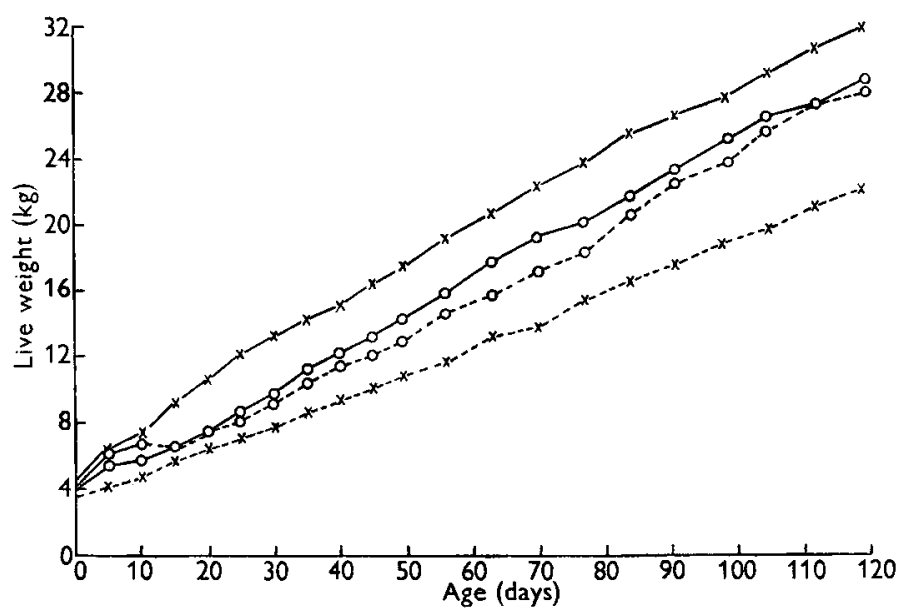

Fig. 4. Weight curves of single lambs (including those on milk-yield trials). $\times-\times$, H.H. lambs (twelve); $0-0$, L.H. lambs (seven); o---o, H.L. lambs (three); $\times---\times$, L.L. lambs (ten).

Table 6. Mean values with their standard errors of body measurements of lambs at birth and weaning

\begin{tabular}{|c|c|c|c|c|}
\hline \multirow{3}{*}{$\begin{array}{l}\text { Group } \\
\text { No. of lambs }\end{array}$} & \multicolumn{4}{|c|}{$\begin{array}{l}\text { Single-born } \\
\text { At birth }\end{array}$} \\
\hline & H.H. & L.H. & L.L. & H.L. \\
\hline & 12 & 7 & 10 & 3 \\
\hline Poll-rump length $(\mathrm{cm})$ & $44 \cdot 7 \pm 0 \cdot 76$ & $40 \cdot I \pm I \cdot 00$ & $4 I \cdot 5 \pm 0 \cdot 84$ & $46 \cdot 7 \pm I \cdot 53$ \\
\hline Shoulder height $(\mathrm{cm})$ & $37 \cdot 2 \pm 0.54$ & $32 \cdot 7 \pm 0 \cdot 70$ & $35.0 \pm 0.59$ & $38 \cdot 2 \pm 1 \cdot 08$ \\
\hline Girth (cm) & $37 \cdot 9 \pm 0.53$ & $32 \cdot 5 \pm 0.69$ & $35^{\cdot 1} \pm 0.5^{8}$ & $37 \cdot 9 \pm I \cdot 06$ \\
\hline Weight $(\mathrm{g}) \div$ shoulder height $(\mathrm{mm})$ & $12 \cdot 7 \pm 0 \cdot 3^{8}$ & $10 \cdot 0 \pm 0 \cdot 49$ & $10.3 \pm 0.41$ & $12 \cdot 8 \pm 0.75$ \\
\hline \multirow[t]{2}{*}{$\begin{array}{l}\text { Weight/shoulder height quotient as } \\
\text { percentage of that of H.H. groups }\end{array}$} & 100 & 79 & $8 \mathrm{I}$ & 100 \\
\hline & \multicolumn{4}{|c|}{ At weaning ( 7 weeks of age) } \\
\hline Length, sternum to ischium $(\mathrm{cm})$ & $60.0 \pm 0.97$ & $60 \cdot 6 \pm I \cdot 28$ & $53 \cdot 3 \pm 1 \cdot 07$ & $57 \cdot 9 \pm 1 \cdot 95$ \\
\hline Width over tuber coxae $(\mathrm{cm})$ & $14.8 \pm 0.33$ & $13 \cdot 0 \pm 0.44$ & $13.3 \pm 0.37$ & $13.9 \pm 0.67$ \\
\hline Shoulder height $(\mathrm{cm})$ & $55^{\circ} \pm 0.59$ & $53 \cdot 6 \pm 0.77$ & $50.6 \pm 0.64$ & $55 \cdot 3 \pm 1 \cdot 17$ \\
\hline Weight $(\mathrm{g}) \div$ shoulder height $(\mathrm{mm})$ & $57 \cdot 4 \pm 2 \cdot 13$ & $53 \cdot 4 \pm 2 \cdot 79$ & $43 \cdot I \pm 2 \cdot 34$ & $50 \cdot 4 \pm 4.26$ \\
\hline \multirow{2}{*}{$\begin{array}{l}\text { Weight/shoulder height quotient as } \\
\text { percentage of that of H.H. groups }\end{array}$} & 100 & 93 & 75 & 88 \\
\hline & \multicolumn{4}{|c|}{ Twin-born } \\
\hline No. of lambs & 9 & 2 & 6 & $\mathbf{I}$ \\
\hline Poll--rump length $(\mathrm{cm})$ & $42 \cdot 1 \pm 0 \cdot 88$ & $36 \cdot 8 \pm x \cdot 87$ & $37 \cdot 0 \pm 1 \cdot 08$ & $4 x \cdot 5 \pm 2 \cdot 64$ \\
\hline Shoulder height $(\mathrm{cm})$ & $34 \cdot 2 \pm 0.62$ & $29 \cdot 5 \pm 1 \cdot 32$ & $31 \cdot 2 \pm 0 \cdot 76$ & $34.9 \pm x \cdot 86$ \\
\hline Girth (cm) & $35 \cdot 5 \pm 0.61$ & $28 \cdot 9 \pm 1 \cdot 29$ & $29.9 \pm 0.75$ & $34 \cdot 0 \pm 1 \cdot 83$ \\
\hline Weight $(\mathrm{g}) \div$ shoulder height $(\mathrm{mm})$ & $10.2 \pm 0.44$ & $7 \cdot 3 \pm 0.92$ & $7 \cdot 7 \pm 0 \cdot 53$ & $9 \cdot 7 \pm 1 \cdot 3 I$ \\
\hline \multirow[t]{2}{*}{$\begin{array}{l}\text { Weight/shoulder height quotient as } \\
\text { percentage of that of H.H. groups }\end{array}$} & 100 & 71 & 75 & 95 \\
\hline & \multicolumn{4}{|c|}{ At weaning ( 17 weeks of age) } \\
\hline Length, sternum to ischium $(\mathrm{cm})$ & $57 \cdot 8 \pm 1 \cdot 12$ & $57 \cdot 4 \pm 2 \cdot 3^{8}$ & $54 \cdot 6 \pm \pm \cdot 38$ & $51 \cdot 2 \pm 3 \cdot 37$ \\
\hline Width over tuber coxae $(\mathrm{cm})$ & $14.1 \pm 0.39$ & $14.3 \pm 0.82$ & $13.0 \pm 0.47$ & $I I \cdot 3 \pm I \cdot I 6$ \\
\hline Shoulder height $(\mathrm{cm})$ & $52 \cdot 3 \pm 0.68$ & $49^{\prime} 2 \pm I \cdot 44$ & $49.8 \pm 0.83$ & $47 \cdot 9 \pm 2 \cdot 03$ \\
\hline $\begin{array}{l}\text { Weight }(\mathrm{g}) \div \text { shoulder height }(\mathrm{mm}) \\
\text { Weight/shoulder height quotient as }\end{array}$ & $\begin{array}{c}53 \cdot 0 \pm 2 \cdot 46 \\
100\end{array}$ & $\begin{array}{c}54 \cdot 3 \pm 5 \cdot 22 \\
102\end{array}$ & $45^{\prime} 4 \pm \frac{1}{86} 3^{\circ 02}$ & $36 \cdot 5 \pm 7 \cdot 39$ \\
\hline
\end{tabular}


lambs were also inferior to the H.H. at weaning, though singles were slightly better than the corresponding L.L. The surviving twin in the H.L. group was the poorest of all. The L.H. lambs were at weaning much superior to the L.L. lambs and equalled the H.H. lambs in body length in the singles and in body length, body width and shoulder-height/weight quotient, but not in shoulder height, in the twins, though it must be pointed out that there were only two twins in the L.H. group.

Udder size. The udder width of all ewes was measured at lambing. In non-pregnant ewes of the same breed and age the average width of the undeveloped udder was $8.2 \mathrm{~cm}$ for low-plane and 9.4 for high-plane ewes. In the present experiment the mean udder width of low-plane ewes bearing singles was $14.9 \mathrm{~cm}$ and for those bearing twins $12.4 \mathrm{~cm}$. The udders of the high-plane ewes measured 19.2 and $18.7 \mathrm{~cm}$, respectively. It is thus obvious that udder development was severely retarded in the low-plane group, more particularly in those bearing twins. A study has therefore been made of factors likely to affect, and of those that may be affected by, udder size.

Table of regression coefficients. The first variable has always been taken as the dependent variable. Unless otherwise stated, the standard error is based on 6 degrees of freedom (d.f.). (In all the following relationships there was a distinct separation into high and low-plane groups. The high-low group, containing only four lambs, did not warrant examination.)

(I) Total milk yield ( $\mathrm{kg})$ and mating weight $(\mathrm{kg})$.

$$
\begin{aligned}
& \text { H.P. } \quad b=-0.61 \pm 0.23^{*} \\
& \text { L.P. } \quad b=-0.70 \pm 0.40 \mathrm{NS}
\end{aligned}
$$

(2) Total milk yield (kg) and weight post partum $(\mathrm{kg})$.

H.P. $\quad b=-0.47 \pm 0.32 \mathrm{NS}$

L.P. $b=-0.76 \pm 0.68 \mathrm{NS}$

(3) Udder width (cm) and weight post partum ( $\mathrm{kg})$.

$$
\begin{array}{lcc} 
& \text { Singles } & \text { Twins } \\
\text { H.P. } & b=0.21 \pm 0.04^{* * *}(\mathrm{I} 4 \text { d.f.) } & b=0.05 \pm 0.03 \text { NS (12 d.f.) } \\
\text { L.P. } & b=0.05 \pm 0.04 \text { NS (20 d.f.) } & b=0.14 \pm 0.08 \text { NS (18 d.f.) }
\end{array}
$$

(4) Udder width $(\mathrm{cm})$ and weight change of ewes during latter half of gestation $(\mathrm{kg})$.

$$
\text { All groups } \quad b=0.09 \pm 0.09 \text { NS (67 d.f.) }
$$

(5) Total milk yield ( $\mathrm{kg}$ ) and udder width $(\mathrm{cm})$.

$$
\begin{aligned}
& \text { H.P. } \quad b=-6.96 \pm 0.84^{* * *} \\
& \text { L.P. } \quad b=3.3 \mathrm{I} \pm \mathrm{I} \cdot 25^{*}
\end{aligned}
$$

(6) Udder width $(\mathrm{cm})$ and birth weight of lambs $(\mathrm{kg})$.

\section{Singles}

H.P. $\quad b=0.24 \pm 0.83$ NS (14 d.f.)

L.P. $\quad b=-\mathrm{I} \cdot 18 \pm 0 \cdot 4^{*}$ ( 20 d.f.)
Twins

$b=\mathrm{I} \cdot 27 \pm 0.64 \mathrm{NS}$ (12 d.f.)

$b=-0.34 \pm 0.84 \mathrm{NS}$ (I 6 d.f.) 
(7) Weight increment of lambs ( $\mathrm{kg}$ ) and milk yield over corresponding period $(\mathrm{kg})$.
$5^{-28}$ days
H.P. $\quad b=0.028 \pm 0.008 P<0.02$
L.P. $b=0.036 \pm 0.004^{* * *}$
28-9r days
$b=-0.06 \pm 0.12 \mathrm{NS}$
$b=0.26 \pm 0.17 \mathrm{NS}$

(8) Weight increment of lambs $(\mathrm{kg})$ and udder width $(\mathrm{cm})$.
$5^{-28}$ days
H.P. $\quad b=0.07 \pm 0.15$ NS (10 d.f.)
28-9I days
$b=-0.25 \pm 0 \cdot 74 \mathrm{NS}$
$b=0.26 \pm 0.62 \mathrm{NS}$
L.P. $b=0.69 \pm 0.30^{*}(8$ d.f. $)$

NS Not significant.

* Significant at $5 \%$ level.

*** Significant at $0.1 \%$ level.

Comment may be made on a few of these relationships. In relationship no. 5 one can only assume that in the high plane the udders had reached their maximum capacity for milk secretion and that any further increase in size was probably the result of excess fleshiness, which in turn inhibited milk yield. With no. 6, it is suggestive, though not statistically significant, that in the high-plane ewes bearing twins udder size was positively related to lamb size. In the low-plane group the correlation was negative and indicates that there was competition between the lamb and udder development. In no. 7 the relationship in the 5-28 day period was closer than in the later period, probably because the lambs were almost entirely dependent on milk during the early period, but in the later period the milk effect was masked by the consumption of trough feed.

Since in the low-plane group udder width and milk yield were positively correlated (no. 5), it is to be expected that in no. 8 gain in weight would be associated with udder width.

\section{DISCUSSION}

It could be argued that, because the ewes in the present experiment were indoors, i.e. managed under artificial conditions for the ewe, the results may bear no relation to those likely to occur under natural conditions. However, any controlled experiment involving animals creates conditions to some degree artificial. The purpose of this experiment was to obtain results on ewes maintained at widely different planes of nutrition during late pregnancy and lactation. The terms 'high plane' or 'low plane' are relative and may have different meanings in the minds of different workers. Our high-plane ewes were no better fed than many well-managed flocks on arable land, and the low-plane ones were no worse fed than very many ewes on the barer hills of Britain where, even in a good year, one may expect a $70 \%$ lamb crop by weaning time and a crop as low as $45 \%$ at weaning in a year of prolonged snow.

From the present results there can be no doubt as to the merits of good nutrition during late pregnancy and lactation. The high-plane ewes had no difficulty in producing and rearing good healthy well-fleshed lambs. Ewes made to lose some weight 
or to gain very little produced poor lambs, particularly when these were twins, and had a poor milk supply despite fairly liberal feeding after lambing.

We are not aware of other published records of the milk yield of ewes obtained by the tedious method of daily recording. Most yields have been estimated from $24 \mathrm{~h}$ periods once weekly, a method having the advantage that many more ewes can be dealt with in one season. The milk yields of the present high-plane ewes were lower than those recorded by Wallace (1948), though his ewes were Border-Leicester $x$ Cheviot in their third or fourth lactations, or Suffolks of various ages. The yields in the present work for both high- and low-plane were also lower than those recorded by Barnicoat et al. (1949), who used 5-year-old Romney ewes. Their high-plane ewes yielded 26 gal. and their low-plane ones 13 gal. in 12 weeks, compared with 20 and I I gal., respectively, in $12-13$ weeks in the present experiment. Yet in spite of these lower yields, our high-plane lambs weighed $56 \frac{1}{2} \mathrm{lb}$. and the low-plane $40 \mathrm{lb}$. at 12 weeks compared with 47 and $3 \circ \frac{1}{2} \mathrm{lb}$, , respectively, for their Romney $\times$ Southdowns on limited pasture. However, their planes of nutrition were not so divergent as ours, since during the last 6 weeks of gestation the high-plane ewes gained at about the same rate as ours and the low-plane ones gained $8 \mathrm{lb}$. compared with a loss of about $2 \mathrm{lb}$. for ours.

Experience at this Institute has shown that pregnant ewes of so low a nutritional status as those in the present low-plane group will take some time to adjust themselves to additional food offered immediately after lambing. This fact may enable our results to be reconciled with those of Coop (1950), who concluded that nutrition during lactation has more effect on the lamb than nutrition during late pregnancy. Again, it has to be pointed out that, judging from our experience, the difference in birth weight of under $\frac{1}{2} \mathrm{lb}$. per head for single lambs in Coop's (1950) experiments suggests that even his low-plane ewes were in good thriving condition at lambing. They would therefore have better udder development than ours and be able to take immediate advantage of the additional food offered after lambing.

The udder of a well-fed ewe begins to develop more than 6 weeks before lambing. When udder development at lambing time has been severely retarded, as in our lowplane ewes, it can hardly be expected that additional food given after lambing will enhance the milk supply quickly enough to benefit the lambs during the time they are most dependent on it, the first 6 weeks of life.

It is common practice to 'steam-up' dairy cows for some weeks before calving, so that they may be in a good condition and have good udder development at calving. The results presented here suggest that the same practice is worth while for the ewe. They further suggest that, though nutrition during late pregnancy greatly affects the vitality of the newborn lamb, it has perhaps an even greater effect on the milk supply of the ewe.

\section{SUMMARY}

I. The milk yield of 2-year-old housed Sutherlandshire Cheviot ewes on a fairly high plane of nutrition during late gestation and lactation, and suckling one lamb, was approximately 20 gal. in 13 weeks lactation, compared with I I gal. for those maintained on little more than half the quantity of nutrients supplied to the high-plane 
ewes. Substantial increases in nutrients offered to the low-plane animals immediately after lambing did not increase the milk supply quickly enough to be of full benefit to the lambs.

2. On a low plane of nutrition increased birth weight of lamb had a retarding effect on udder development of the ewe at lambing, and udder size at lambing reflected milk yield and consequent weight increment of lamb. These effects were not evident in ewes on a high plane of nutrition.

3. Lambs transferred from low-plane to high-plane mothers at birth were able to take advantage of the greater milk supply, though at weaning they were still smaller than those conceived and reared by high-plane ewes.

4. Lambs transferred at birth from high-plane to low-plane ewes had a high mortality; as a result, too few remained at weaning for definite conclusions to be drawn from them.

5. It is concluded that undernutrition in the later stages of pregnancy greatly affects the vitality of the newborn lamb and has a still severer effect on the milk supply of the ewe, particularly in early lactation.

We are indebted to Mr A. W. Boyne of the Statistical Department for the statistical analyses.

\section{REFERENCES}

Barnicoat, C. R., Logan, A. G. \& Grant, A. I. (1949). F. agric. Sci. 39, 44.

Coop, I. E. (1950). $\mathscr{F}$. agric. Sci. 40, 31 I.

Thomson, A. M. \& Thomson, W. (1948-9). Brit. F. Nutr. 2, 290.

Wallace, L. R. (1948). F. agric. Sci. 38, 93 .

Wood, 'T. B. \& Woodman, H. E. (1939). Bull. Minist. Agric., Lond., no. $4^{8 .}$ 